\title{
NOTE
}

\section{Additional isotopic measurements on Japanese ore leads}

\author{
Kazuo Sato ${ }^{1,2,3}$, William F. Slawson ${ }^{2}$ and Ernest R. Kanasewich ${ }^{3}$ \\ Earthquake Research Institute, University of Tokyo, \\ Bunkyo-ku, Tokyo, Japan ${ }^{1}$, Department of Geophysics \\ and Astronomy, University of British Columbia, \\ Vancouver, B. C., Canada ${ }^{2}$ and Department of \\ Physics, University of Alberta, Edmonton, Alberta, \\ Canada $^{3}$
}

(Received June 18, 1973)

\begin{abstract}
Isotope ratios measured for selected Japanese ore leads are corrected to the absolute scale and compared with some available data for other Japanese samples. The isotopic feature pointed out in the previous work is confirmed: The data for the Miocene vein-type deposits are very similar to the lead isotope ratios available for the Miocene strata-bound (Kuroko) deposits, northern and central Honshu volcanic rocks and pelagic sediments near the Japan Trench.
\end{abstract}

\section{INTRODUCTION}

It was reported in 1955 (SAKAI et al.) and 1958 (SAKAI and SATO) that the typical Japanese ore leads extracted mainly from vein-type deposits of Mesozoic to Cenozoic ages have only a small variation in isotopic composition. The analytical data were observed to fall within the range of variation for modern ordinary leads from other parts of the world. The data have been quoted in the lead isotopic studies of igneous rocks by ShIMIzU (1970) and SAITO and MiYAZAKI (1972) to represent the Japanese ore leads. The similarity in isotopic composition of lead between the ores and some of the igneous rocks has been mentioned.

Recently lead isotopic measurements were made on the Miocene strata-bound type (Kuroko) deposits in Japan (SATo and SASAKI, 1973). Comparisons of these data with the isotope ratios of the Miocene vein-type deposits and the values available for other samples in Japan indicated a remarkable isotopic uniformity for various types of material existing over an extensive area. The vein lead data used in this observation were also taken from the early works by SAKAI et al. (1955) and SAKAI and SATO (1958).

These comparisons, which are based on the results obtained by means of different analytical methods, may have been attended with considerable uncertainties 
for lack of information in order to estimate correction factors for mass spectrometer discriminations. This report presents additional isotopic data for Japanese ore leads to confirm the isotopic feature of Miocene ore leads observed in the previous work. The deposits analyzed were mostly of vein type. Some of the samples were taken from the same localities as those selected before.

\section{EXPERIMENTAL}

Isotope measurements were carried out on a $90^{\circ}, 30 \mathrm{~cm}$ gas source mass spectrometer at the University of British Columbia. The procedures were similar to those described by Ostic et al. (1967). Pressure-scattering (tail effect of neighbouring peaks) corrections were applied to all measurements. A suite of samples of similar isotopic compositions were analyzed within a period of a few hours to minimize the effect of long-term instrumental variations. For most of the samples, small differences in the isotope ratios relative to a local standard were thus obtained. The differences were corrected on the basis of an assumption concerning "loop-closure errors" (OsTic et al.. 1967). In like manner, the local standard was measured relative to the Broken Hill standard lead (UBC No.1, Toronto T-1003 etc.). The samples were thus ultimately compared with the Broken Hill standard. The absolute values of this standard lead have been estimated by COOPER et al. (1969) with the double-spiking technique and by STACEY et al. (1969) with the triple-filament technique. All data obtained in this work were normalized to the values of COOPER et al., ${ }^{206} \mathrm{~Pb} /{ }^{204} \mathrm{~Pb}=16.003,{ }^{207} \mathrm{~Pb} /$ ${ }^{204} \mathrm{~Pb}=15.390,{ }^{208} \mathrm{~Pb} /{ }^{204} \mathrm{~Pb}=35.660$. The two sets of data for the Broken Hill standard are in excellent agreement so that the difference is negligible for the present purpose. The over-all uncertainty in the isotope ratios adjusted to the absolute scale is estimated to be $0.2 \%$ at the $90 \%$ confidence level except for the values of three specimens. For the specimens, Nos.510, 520 and 566, the looping procedure stated above was not completed. Based on the data of duplicate analyses, the precision of $0.3 \%$ is obtained for the isotope ratios of these three specimens.

\section{RESUltS}

The lead isotope ratios obtained are listed in Table 1 and are plotted in Fig. 1. The data fall within a small range even though they represent various mining districts distributed over an extensive area. The prime feature of Japanese ore leads as has been pointed out in the early works is also remarkable in the present data. The absolute growth curves for certain large strata-bound ore bodies determined by Cooper et al. (1969) are indicated by solid lines in Fig.1. Although the significance of the isotopic pattern exhibited by these strata-bound ore leads remains unclear, it is generally accepted that their growth curve is a representative of an evolutional sequence of ter- 
Table 1. Isotope ratios of Japanese ore leads ${ }^{1}$ )

\begin{tabular}{|c|c|c|c|c|c|c|}
\hline Sample No. & Location & Type of deposit $\left.{ }^{3}\right)$ & Mineral & ${ }^{206} \mathrm{~Pb} /{ }^{204} \mathrm{~Pb}$ & ${ }^{207} \mathrm{~Pb} /{ }^{204} \mathrm{~Pb}$ & ${ }^{208} \mathrm{~Pb} /{ }^{204} \mathrm{~Pb}$ \\
\hline \multicolumn{7}{|c|}{ Pre-Miocene (Cretaceous to early Tertiary) mineralizations $\left.{ }^{4}\right)$} \\
\hline 511 & $\begin{array}{l}\text { Taro mine, } \\
\text { Iwate-ken }\end{array}$ & $\begin{array}{l}\text { polymetallic } \\
\text { strata-bound }\end{array}$ & galena & 18.70 & 15.64 & 38.68 \\
\hline $520^{2)}$ & $\begin{array}{l}\text { Nan-etsu mine, } \\
\text { Niigata-ken }\end{array}$ & $\begin{array}{l}\mathrm{Pb}-\mathrm{Zn}(-\mathrm{Cu}) \\
\text { vein }\end{array}$ & galena & 18.42 & 15.57 & 38.47 \\
\hline $566^{2)}$ & $\begin{array}{l}\text { Ikuno mine, } \\
\text { Hyogo-ken }\end{array}$ & $\begin{array}{l}\text { polymetallic } \\
\text { vein }\end{array}$ & galena & 18.27 & 15.47 & 38.27 \\
\hline \multicolumn{7}{|c|}{ Miocene mineralizations ${ }^{4)}$} \\
\hline 515 & $\begin{array}{l}\text { Daira mine, } \\
\text { Akita-ken }\end{array}$ & $\begin{array}{l}\mathrm{Pb}-\mathrm{Zn}(\mathrm{Cu}-) \\
\text { vein }\end{array}$ & galena & 18.14 & 15.52 & 38.39 \\
\hline 516 & $\begin{array}{l}\text { Hanaoka mine, } \\
\text { Akita-ken }\end{array}$ & $\begin{array}{l}\text { polymetallic } \\
\text { strata-bound } \\
\text { (Kuroko) }\end{array}$ & black ore & 18.44 & 15.54 & 38.45 \\
\hline 517 & $\begin{array}{l}\text { Osarizawa mine, } \\
\text { Akita-ken }\end{array}$ & $\begin{array}{l}\mathrm{Cu}-\mathrm{Pb}-\mathrm{Zn} \\
\text { vein }\end{array}$ & $\begin{array}{l}\text { supergene } \\
\mathrm{Pb}, \mathrm{Cu} \text {-sulfates }\end{array}$ & s $\quad 18.44$ & 15.51 & 38.39 \\
\hline 519 & $\begin{array}{l}\text { Mikawa mine, } \\
\text { Niigata-ken }\end{array}$ & $\begin{array}{l}\mathrm{Cu}-\mathrm{Pb}-\mathrm{Zn} \\
\text { vein }\end{array}$ & galena & 18.46 & 15.59 & 38.66 \\
\hline 521 & $\begin{array}{l}\text { Budo mine, } \\
\text { Niigata-ken }\end{array}$ & $\mathrm{Pb}-\mathrm{Zn}$ vein & galena & 18.34 & 15.42 & 38.21 \\
\hline 522 & $\begin{array}{l}\text { Hosokura mine, } \\
\text { Miyagi-ken }\end{array}$ & $\mathrm{Pb}-\mathrm{Zn}$ vein & galena & 18.54 & 15.59 & 38.55 \\
\hline 525 & $\begin{array}{l}\text { Ogoya mine, } \\
\text { Ishikawa-ken }\end{array}$ & $\begin{array}{l}\mathrm{Cu}-\mathrm{Pb}-\mathrm{Zn} \\
\text { vein }\end{array}$ & pyromorphite & 18.58 & 15.47 & 38.74 \\
\hline $510^{2)}$ & $\begin{array}{l}\text { Taisyu mine, } \\
\text { Nagasaki-ken }\end{array}$ & $\mathrm{Pb}-\mathrm{Zn}$ vein & galena & 18.33 & 15.51 & 38.46 \\
\hline
\end{tabular}

1) The data were adjusted to the absolute scale (see text).

2) Data based on the duplicate analyses but not "loop-closure" technique.

3) Detailed descriptions are given by Geological Survey of Japan (1956) and TATSUMI et al. (1970).

4) Based on the age data given in KAWANO and UEDA (1966) (Nan-etsu mine), ISHIHARA and Shibata (1972) (Ikuno mine) and TATSUMI et al. (1970) (other mines).

restrial leads on some global scale (e.g. Armstrong, 1968). The Japanese ore leads plot close to the modern point of the strata-bound ore lead system, but in the ${ }^{207} \mathrm{~Pb} /{ }^{204} \mathrm{~Pb}$ vs. ${ }^{206} \mathrm{~Pb} /{ }^{204} \mathrm{~Pb}$ diagram, appear to lie slightly below the growth curve.

Of the three pre-Miocene samples analyzed, the lead from Taro mine shows small J-type anomaly while the leads from Ikuno mine and Nan-etsu mine are perhaps of ordinary class. Most of the ores belonging to Miocene mineralizations have ordinary isotopic composition. Namely the isotope ratios for most of the samples studied nearly fit a closed system model.

\section{Comparison with Other Lead Isotopic Data}

The Miocene ores other than that of Taisyu mine (No.510) occur in the area of Miocene volcanic series ("Green Tuff" region) which is a large tectonic unit extending from the northeast to southwest part of the Japanese Islands (see for example TATSUMI et al., 1970). There are several points that should be noted concerning the isotopic 

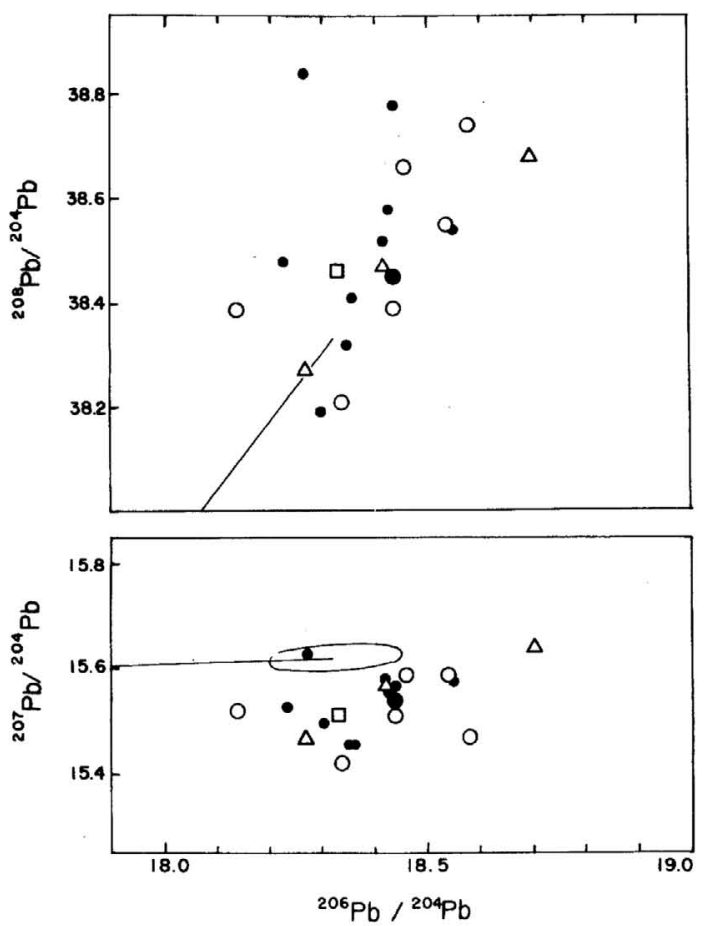

Fig.1. ${ }^{207} \mathrm{~Pb} /{ }^{204} \mathrm{~Pb}$ vs. ${ }^{206} \mathrm{~Pb} /{ }^{204} \mathrm{~Pb}$ and ${ }^{208} \mathrm{~Pb} /{ }^{204} \mathrm{~Pb}$ vs. ${ }^{206} \mathrm{~Pb} /{ }^{204} \mathrm{~Pb}$ diagrams for Japanese ore leads. Open circles, Miocene veins in the Green Tuff region; solid circles, Miocene strata-bound (Kuroko) type ores in the Green Tuff region (small solid circles are the data from SATO and SASAKI, 1973); square, Taisyu mine (Miocene); triangles, pre-Miocene deposits. The lines represent the growth curves for large strata-bound ore-bodies determined by COOPER et al. (1969). The present-day ${ }^{238} \mathrm{U} /{ }^{204} \mathrm{~Pb}(\mu)$ and ${ }^{232} \mathrm{Th} /{ }^{238} \mathrm{U}(\kappa)$ ratios of the system are 8.79 and 3.90 , respectively. Looped area indicates approximately the uncertainty in modern lead point estimated by COOPER et al.

data for this area. The samples analyzed in this work were taken from hydrothermal vein-type deposits with one exception (No.516). The sample No.516 is a black ore from the strata-bound, Kuroko type deposits of Hanaoka mine which occur also in the Green Tuff region. As more isotopic data are available for other Kuroko type deposits in the region (SATO and SASAKI, 1973), they are also plotted in Fig.1 for comparison. It is clear that at this level of precision there is no lead isotopic distinction between the strata-bound and vein-type deposits. 
Table 2. Isotopic composition of lead in Green Tuff ores, Cenozoic volcanic rocks, Mesozoic plutonic rocks and Pacific pelagic sediments near the Japan Trench (values adjusted to the absolute scale)

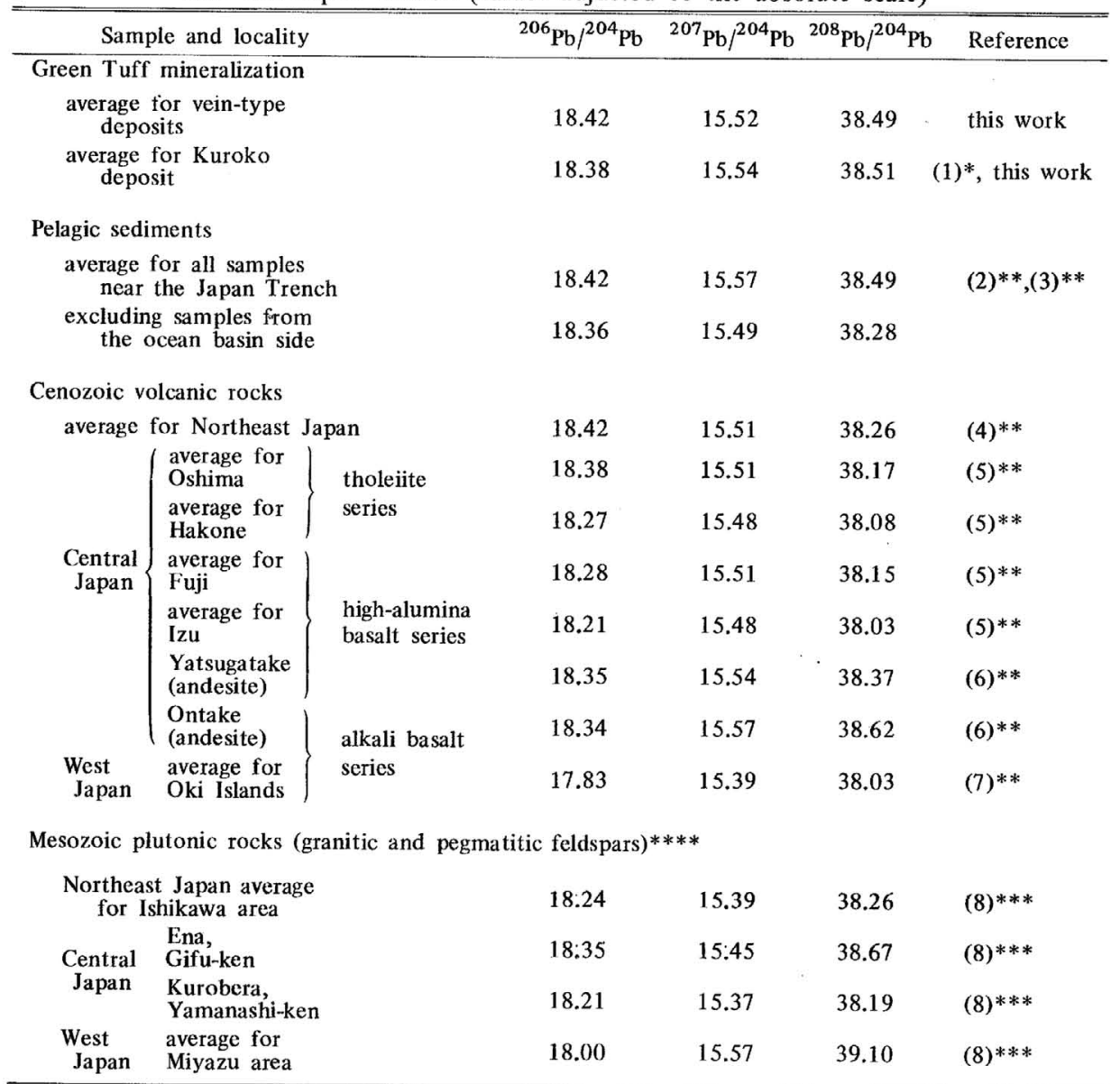

* Values already adjusted to the absolute scale.

** Correction factors were derived from the absolute isotope ratios for the CIT standard lead (CATANZARO, 1968) and the values for this standard given in each paper. Although the papers (4) and (7) do not contain isotopic data for standard samples, it has been reported that the measurements were done under experimental conditions similar to those indicated in (5). Therefore, the same correction factors were applied to the data from these papers.

*** The data have been normalized to the Broken Hill standard lead. The absolute values for this standard given by COOPER et al. (1969) were used.

**** SHIMIZU (1970) reported the isotopic analyses of lead on the granitic rocks from Abukuma (northeast Japan) and Sidara (central Japan) areas, but no information about standard samples has been provided. Their average values are as follows: 


$\begin{array}{crrr}\text { Abukuma av. for K-feldspars } & 18.70 & 15.74 & 38.93 \\ \text { av. for total rocks } & 18.70 & 15.63 & 38.83 \\ \text { Sidara av. for K-feldspars } & 18.55 & 15.70 & 38.91 \\ \text { av. for total rocks } & 18.53 & 15.67 & 38.83\end{array}$

If these data were obtained under experimental conditions similar to those cited in Table 2 , the adjustment to the absolute scale would result in a mass-dependent shift of the isotope ratios such as diminution of ${ }^{206} \mathrm{~Pb} /{ }^{204} \mathrm{~Pb}$ ratios by about $1 \%$.

References: (1) Sato and SASAKi (1973), (2) ChOW and PATterson, 1959, (3) ChOW and TATSumoto, 1964, (4) Hedge and KNIGHT, 1969, (5) TATSUMOTO and KNIGHT, 1969, (6) TATSUMOTO, 1969, (7) KuRASAWA, 1968, (8) SAITO and MIYAZAKI, 1972.

In Table 2 are compared the average values for the Miocene veins and Kuroko type ores with the data for Cenozoic and Mesozoic igneous rocks in Japan (KurasawA, 1968; Hedge and KNight, 1969; Tatsumoto, 1969; Tatsumoto and Knight, 1969; SAITO and MIYAZAKI, 1972). As the abundance of igneous materials is significant in Japan, their average isotopic composition is expected to be not far from the average value of Japanese crustal leads. The pelagic sediment leads in a given oceanic basin are thought to be derived mostly from the adjacent land masses. Thus, the average isotope ratios of the sediment leads near the Japan Trench (CHOW and PATterson, 1959; ChOW and TAтsumoto, 1964) are also included in Table 2. The values listed in the table are those adjusted to the absolute scale. The corrections were made on the basis of the isotopic data for either the Broken Hill standard or the CIT shelf standard reported in each paper. For the absolute ratios of the CIT standard, the values given by Catanzaro (1968) were used*.

The similarity in isotopic composition of lead between the tholeiites from central Japan and the pelagic sediments near the Japan Trench was first noticed by Tatsumoto (1969). The similarity among the Miocene ore leads, the igneous rock leads from the central and northeast Japan and the pelagic sediment leads near the Japan Trench was also pointed out by SATO and SASAKI (1973). The data in Table 2 clearly confirm these observations.

\section{ACKNOWLEDGMENTS}

The ore samples were provided by Dr. H. IMAI, Department of Mineral Development Engineering, University of Tokyo. Helpful discussions with Dr. R. D. RuSsEll, Department of Geophysics and Astronomy, University of British Columbia and Dr. A. SASAKI, Geological Survey of Japan are gratefully acknowledged. The work is supported by the National Research Council of

* COMPSTON and OVERSBy (1969) have also reported the absolute values of this standard which are slightly lower than those of CATANZARO. The differences are about $0.15,0.27$ and $0.33 \%$ for ${ }^{206} \mathrm{~Pb} /{ }^{204} \mathrm{~Pb},{ }^{207} \mathrm{~Pb} /{ }^{204} \mathrm{~Pb}$ and ${ }^{208} \mathrm{~Pb} /{ }^{204} \mathrm{~Pb}$, respectively. 
Canada Grant Nos. A720 and A2633. The research at the University of British Columbia was for the most part made during K. SATO's tenure of the Canadian Exploration Co. Fellowship.

\section{REFERENCES}

ARMSTRONG, R. L. (1968) A model for the evolution of strontium and lead isotopes in a dynamic earth. Rev. Geophys. 6, 175-199.

CATANZARo, E. J. (1968) Absolute isotopic abundance ratios of three common lead reference samples. Earth Planet. Sci. Letters 3, 343-346.

ChOW, T. J. and PATTERSON, C. C. (1959) Lead isotopes in manganese nodules. Geochim. Cosmochim. Acta 17, 21-31; (correction, ibid. 26, 973, 1962).

Chow, T. J. and TAтsumoto, M. (1964) Isotopic composition of lead in the sediments near Japan Trench. in Recent research in the fileds of hydrosphere, atmosphere and nuclear geochemistry, ed. Y. MIYAKE, and T. KoYAMA, Maruzen, Tokyo 179-183.

COMPSTON, W. and OVERSBY, V. M. (1969) Lead isotope analyses using a double spike. J. Geophys. Res. 74, 4338-4348.

COOPER, J. A., Reynolds, P. H. and Richards, J. R. (1969) Double spike calibration of the Broken Hill standard lead. Earth Planet. Sci. Letters 6, 467-478.

Geological Survey of Japan (1956) Mineral resources of Japan (Nippon Kosanshi), Part BI-b, Copper, lead and zinc: Kinuta Shobo, Tokyo, 395p (in Japanese).

HEDGE, C. E. and KNIGHT, R. J. (1969) Lead and strontium isotopes in volcanic rocks from northern Honshu, Japan. Geochem. J. 3, 15-24.

ISHIHARA, S. and SHIBATA, K. (1972) Re-examination of the metallogenic epoch of the IkunoAkenobe Province in Japan. Mining Geology (Tokyo) 22, 67-73.

KAWANO, Y. and UEDA, Y. (1966) K-Ar dating on the igneous rocks in Japan (IV) - granitic rocks in northeastern Japan. J. Japanese Assoc. Min. Petr. Econ. Geol. 56, 41-55 (in Japanese with English abstract).

KURASAWA, H. (1968) Isotopic composition of lead and concentration of uranium, thorium and lead in volcanic rocks from Dogo of the Oki Islands, Japan. Geochem. J. 2, 11-28.

Ostic, R. G., Russell, R. D. and Stanton, R. L. (1967) Additional measurements of the isotopic composition of lead from stratiform deposits. Canadian J. Earth Sci. 4, 245-269.

SAITO, N. and MIYAZAKI, A. (1972) Isotopic composition of lead in pegmatitic feldspars of Japan. J. Geol. Soc. Japan 78, 341-346 (in Japanese with English abstract).

SAKAI, H., HONDA, M. and MiNAMI, E. (1955) Isotopic composition of the common lead in Japan. Bull. Chem. Soc. Japan 28, 533-534.

SAKAI, H. and SATO, K. (1958) Isotopic composition of the common lead of Japan. Geochim. Cosmochim. Acta 15, 1-5.

SATO, K. and SASAKI, A. (1973) Lead isotopes of the black ore "kuroko" deposits from Japan. Econ. Geol. 68, 547-552.

SHIMIZU, N. (1970) Lead isotopic studies on granitic rocks of the Abukuma and Sidara areas in Ryoke-Abukuma metamorphic belt, central Japan. J. Fac. Sci. Univ. Tokyo Sec. 2, 17, 445484.

StaCeY, J. S., DelevauX, M. and UlRYCh, T. J. (1969) Some triple filament lead isotope ratio measurements and the absolute growth curve for single stage leads. Earth Planet. Sci. Letters $6,15-25$. 
TATSUmi, T., SEKine, Y. and KANEHIRA, K. (1970) Mineral deposits of volcanic affinity in Japan: Metallogeny. in Volcanism and ore genesis, ed. T. TATsumi, Univ. of Tokyo Press, $3-47$.

TATSUMOTO, M. (1969) Lead isotopes in volcanic rocks and possible ocean-floor thrusting beneath island arcs. Earth Planet. Sci. Letters 6, 369-376.

TATsumoto, M. and KNIGHT, R. J. (1969) Isotopic composition of lead in volcanic rocks from central Honshu - with regard to basalt genesis. Geochem. J. 3, 53-86. 